\title{
Distribusi Nilai Konduktivitas Lahan Peternakan Ayam di Kecamatan Segedong Kabupaten Mempawah
}

\author{
Erik Saputra Hidayata, Nurhasanaha, Zulfian ${ }^{\text {* }}$
}

aProdi Fisika, FMIPA Universitas Tanjungpura, Jalan Prof. Dr. Hadari Nawawi, Pontianak, Indonesia bProdi Geofisika, FMIPA Universitas Tanjungpura, Jalan Prof. Dr. Hadari Nawawi, Pontianak, Indonesia *Email : zulfian@physics.untan.ac.id

\begin{abstract}
Abstrak
Penelitian ini bertujuan untuk menentukan distribusi nilai konduktivitas lahan peternakan yang tercemar limbah kotoran ayam di Desa Sungai Burung Kecamatan Segedong Kabupaten Mempawah. Parameter yang dihitung yaitu nilai resistivitas dan konduktivitas berdasarkan dari nilai arus dan beda potensial yang terukur di lapangan. Metode yang digunakan adalah metode resistivitas dengan metode perhitungannya menggunakan metode kuadrat terkecil. Hasil penelitian menunjukkan bahwa pola distribusi nilai konduktivitas pada kedalaman 0-15 cm berkisar $7 \mathrm{mS} / \mathrm{m}-18 \mathrm{mS} / \mathrm{m}$ dan pada kedalaman $15-30 \mathrm{~cm}$ berkisar $7 \mathrm{mS} / \mathrm{m}-16 \mathrm{mS} / \mathrm{m}$. Nilai konduktivitas pada kedalaman $0-15 \mathrm{~cm}$ relatif lebih tinggi sedangkan pada kedalaman $15-30 \mathrm{~cm}$ lebih menyebar secara merata.
\end{abstract}

Kata Kunci : konduktivitas, resistivitas, arus, beda potensial

\section{Latar Belakang}

Lapisan tanah yang tercemar oleh limbah kotoran ayam yang mengandung senyawa organik menyebabkan tanah bersifat konduktif. Limbah kotoran ayam memiliki nilai konduktivitas lebih besar dibandingkan dengan air biasa. Limbah peternakan ayam Broiler menyebar tidak hanya melalui tanah, namun juga melalui udara [1]. Pada Penelitian sebelumnya diketahui bahwa peternakan ayam broiler menyebabkan penyebaran polusi di udara. Dalam laporannya Prasetyanto menjelaskan bahwa kandungan udara di sekitar kandang ayam didominasi oleh unsur $\mathrm{H}_{2} \mathrm{~S}$ dan $\mathrm{NO}_{2}$ dengan kadar kelembaban udara $40 \%$ sehingga dapat dihitung bahwa emisi gas per ekor ayam berjumlah $100 \mathrm{mg} /$ hari [2]. Hal ini dapat menyebabkan keadaan kandang menjadi terganggu dan aktivitas industri pada peternakan ayam menurun dikarenakan kualitas lingkungan yang yang buruk. Selain itu, rembesan limbah kotoran ayam juga dapat mencemari air tanah dan berdampak buruk pada lingkungan di sekitarnya, seperti polusi udara yang dapat menyebabkan gangguan pernapasan dan diare yang disebabkan sumber air yang tercemar.

Untuk mengidentifikasi sebaran limbah kotoran ayam dapat digunakan metode geolistrik dengan cara mendeteksi kontras resistivitas medium akibat penyebaran kontaminan (rembesan limbah) di bawah permukaan yang sering diasosiasikan sebagai fluida konduktif. Metode geolistrik dapat digunakan untuk menentukan pencemaran air tanah seperti menganalisis distribusi limbah kelapa sawit dengan mengaplikasikan geolistrik [3] dan untuk mengidentifikasi struktur bawah permukaan [4].

Berdasarkan latar belakang yang telah dipaparkan, maka dalam paper ini dilakukan penelitian tentang distribusi konduktivitas pada lahan peternakan ayam dengan menggunakan metode resistivitas. Selain itu, dilakukan uji sampel untuk melihat pola distribusi konduktivitas pada lahan peternakan berdasarkan sifat tahanan jenis lahan.

\section{Metodologi}

Lokasi peternakan ayam di Desa Sungai Burung Kecamatan Segedong Kabupaten Mempawah (Gambar 1) memiliki luas lahan peternakan sekitar $4.200 \mathrm{~m} 2$. Jarak antara perumahan penduduk dan lokasi kandang ayam berjarak $\pm 80 \mathrm{~m}$. Pada lokasi penelitian terdapat 8 kandang ayam dengan panjang $26 \mathrm{~m}$ dan lebar $6 \mathrm{~m}$ (Gambar 2). Pada lahan peternakan juga terdapat 6 buah kolam besar dan di sekelilingnya terdapat air yang tergenang dan tercemar kotoran ayam. Penelitian ini bertujuan untuk melihat distribusi konduktivitas melalui uji resistivitas untuk melihat pola sebaran yang terjadi di bawah permukaan tanah.

Gambar 2 menjelaskan jumlah lintasan pada lokasi penelitian yang berjumlah empat lintasan yaitu L1, L2, L3 dan L4. Koordinat lintasan 1 (L1) yaitu $0^{0}$ 9' 8" LU, $109^{0}$ 9' 51" - $109^{\circ}$ 9' 53" BT, lintasan 2 (L2) terletak pada koordinat $0^{0}$ 9' 9,6" LU, $109^{0} 9^{\prime} 51^{\prime \prime}-109^{0}$ 9' 53" BT, kemudian lintasan 3 (L3) dan lintasan 4 (L4) terletak pada koordinat $0^{0} 9^{\prime} 10^{\prime \prime} \mathrm{LU}, 109^{\circ} 9^{\prime} 51^{\prime \prime}-109^{\circ} 9^{\prime} 53^{\prime \prime}$ BT dan $0^{0}$ 9' 11" LU, $109^{0}$ 9' 51" - $109^{\circ}$ 9' 53" BT 


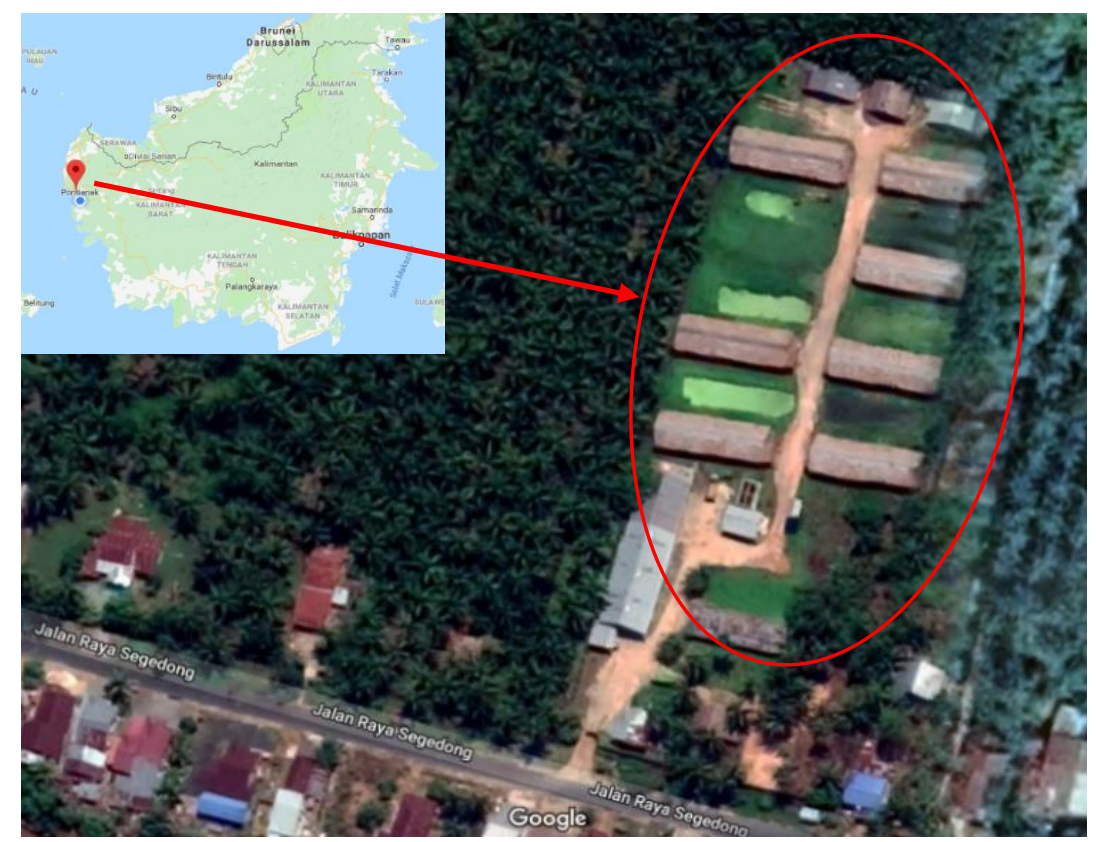

Gambar 1 Lokasi pengambilan data di Desa Sungai Burung Kecamatan Segedong Kabupaten Mempawah. (Sumber: Google Earth)

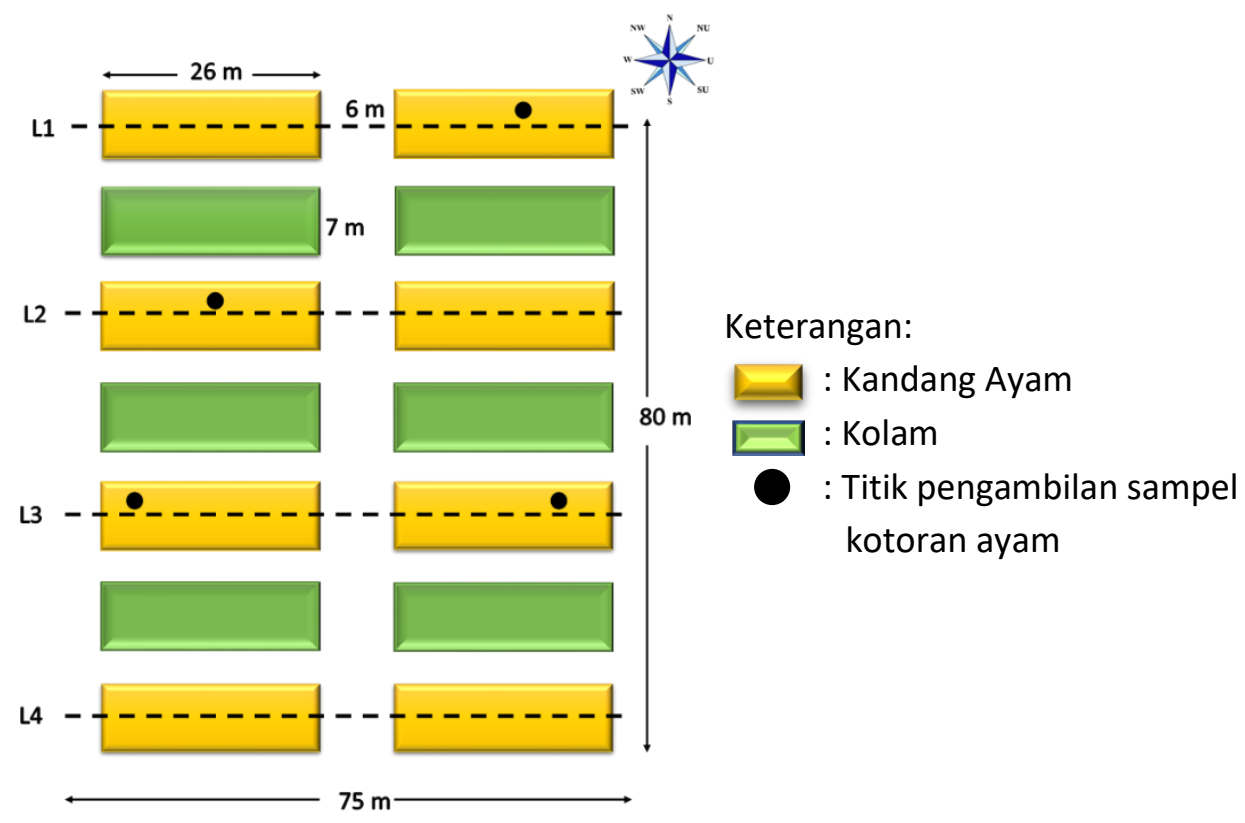

Gambar 2 Sketsa pengambilan sampel

Pada masing-masing lintasan selanjutnya diambil sampel tanah pada kedalaman 0-15 $\mathrm{cm}$ dan 15-30 cm. Pengambilan sampel tanah dengan cara dibor dan kemudian sampel tanah dimasukkan ke dalam paralon yang berdiameter $4,44 \mathrm{~cm}$ dan lebar $15 \mathrm{~cm}$. Pada setiap lintasan diambil sampel dengan jarak $5 \mathrm{~m}$ di setiap titik yang berjumlah 16 buah untuk setiap lintasan.
Pengujian Sampel tanah berjumlah 128 buah, 64 buah sampel tanah di kedalaman 0-15 $\mathrm{cm}$ dan 64 buah lainnya dari kedalaman 15-30 $\mathrm{cm}$. Selain sampel tanah, diambil satu sampel kotoran ayam yang juga dimasukkan kedalam paralon dengan diameter $4,44 \mathrm{~cm}$ dan panjang 15 $\mathrm{cm}$.

Sampel tanah yang ada selanjutnya diukur nilai hambatannya (R). Pengukuran ini menggunakan konsep dari arus yang melewati suatu medium (sampel tanah dan kotoran ayam). 
Setelah diperoleh nilai hambatan, dapat ditentukan nilai resistivitas dan konduktivitasnya dengan menggunakan metode kuadrat terkecil.

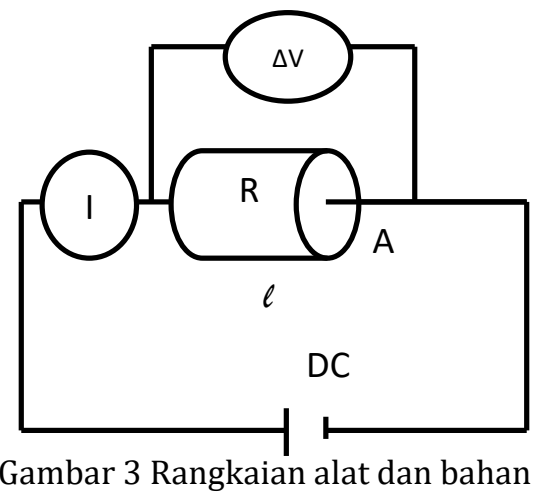

Langkah pertama dalam pengambilan data yaitu menyiapkan peralatan dan bahan berupa multimeter, catu daya dan sampel. Kemudian, alat dan bahan dirangkai menjadi satu seperti pada Gambar 3.

Langkah kedua yaitu mengalirkan arus pada suatu medium dengan cara mengatur nilai tegangan pada catu daya. Tegangan catu daya yang digunakan yaitu 3V, 5V, 7V, 9V, 11V, 13V dan 15V. Selanjutnya dicatat nilai arus yang melewati medium (kotoran ayam dan sampel tanah), kemudian diambil data beda potensial antara ujung-ujung medium. Pengambilan data dilakukan dengan pengukuran berulang sebanyak 3 kali.

Berdasarkan Gambar 3 maka diperoleh hubungan beda potensial, arus dan hambatan yang ditunjukkan oleh Persamaan 1

$$
\Delta \mathrm{V}=\mathrm{RI}
$$

$\mathrm{R}$ sebagai hambatan selaku gradien $(\Omega), \Delta \mathrm{V}$ sebagai beda potensial antar ujung-ujung medium (V) dan I sebagai arus (A). Hubungan ini merupakan hukum ohm yang menyatakan besar arus listrik (I) yang mengalir melalui sebuah penghantar atau Konduktor akan berbanding lurus dengan beda potensial (V) yang diterapkan kepadanya dan berbanding terbalik dengan hambatannya (R). Hambatan suatu medium dapat oleh Persamaan 2

$$
\mathrm{R}=\rho \frac{\mathrm{l}}{\mathrm{A}}
$$

Selanjutnya dengan mensubstitusikan Persamaan 1 dan Persamaan 2 maka diperoleh hubungan

$$
\frac{\Delta \mathrm{V}}{\mathrm{I}}=\rho \frac{\mathrm{l}}{\mathrm{A}}
$$

Sehingga

$$
\Delta \mathrm{V}=\rho \frac{\mathrm{l}}{\mathrm{A}} \mathrm{I}
$$

Rho $(\rho)$ merupakan resistivitas suatu medium $(\Omega \mathrm{m})$ dan A merupakan luas penampang $\left(\mathrm{m}^{2}\right)$ serta $\mathrm{l}$ adalah panjang medium (m).

Pada penelitian ini, nilai resistivitas pada persamaan 4 dapat ditentukan menggunakan metode kuadrat terkecil. Berdasarkan persamaan linear, maka $\rho \frac{\mathrm{l}}{\mathrm{A}}$ adalah hambatan yang merupakan gradien dari grafik $\Delta \mathrm{V}$ dan $\mathrm{I}$. Kemudian hambatan (R) dapat ditentukan berdasarkan metode kuadrat terkecil menggunakan persamaan 5 .

$$
\mathrm{R}=\frac{\mathrm{N} \sum(\mathrm{I} \Delta \mathrm{V})-\sum \mathrm{I} \sum \Delta \mathrm{V}}{N \sum I^{2}-\left(\sum I\right)^{2}}
$$

I merupakan kuat arus yang mengalir melalui medium selaku variabel bebas, $\Delta \mathrm{V}$ menyatakan beda potensial antar ujung-ujung medium selaku variabel terikat dan $\mathrm{R}$ sebagai hambatan yang merupakan gradien dari persamaan linier.

Setelah diketahui nilai hambatan selanjutnya, nilai resistivitas suatu medium dapat ditentukan berdasarkan persamaan 2 . Kemudian nilai konduktivitas dapat ditentukan berdasarkan persamaan 6 .

$$
\sigma=\frac{1}{\rho}
$$

Keterangan:

$\sigma \quad=$ Konduktivitas $(\mathrm{S} / \mathrm{m})$

$\rho=\operatorname{Resistivitas}(\Omega \mathrm{m})$ Luas lahan peternakan tersebut sekitar $4.200 \mathrm{~m} 2$. Jarak antara perumahan penduduk dan lokasi kandang ayam berjarak $\pm 80 \mathrm{~m}$.

Pada lokasi penelitian terdapat 8 kandang ayam dengan panjang $26 \mathrm{~m}$ dan lebar $6 \mathrm{~m}$ (Gambar 2). Pada lahan peternakan juga terdapat 6 buah kolam besar dan di sekelilingnya terdapat air yang tergenang dan tercemar kotoran ayam 


\section{Hasil dan Pembahasan}

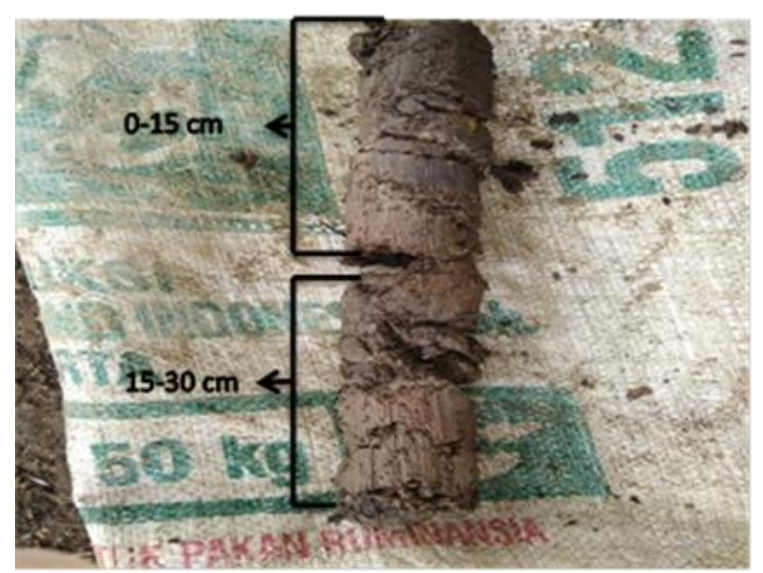

Gambar 4 Bentuk sampel tanah setelah dibor

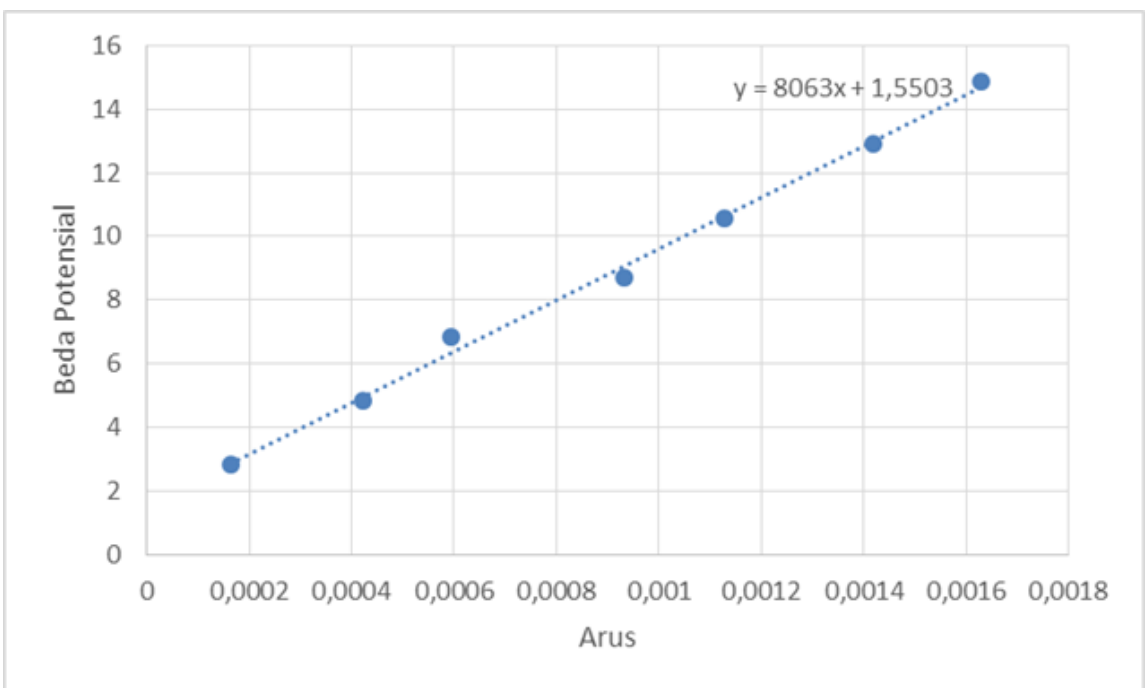

Gambar 5 Grafik beda potensial terhadap arus pada medium (kotoran ayam)

Sampel tanah yang diperlihatkan pada Gambar 4 adalah sampel tanah yang diambil setelah dibor pada kedalaman 0-15 cm dan 15-30 $\mathrm{cm}$. Pada kedalaman 0-15 $\mathrm{cm}$ terlihat bahwa tanah di bagian atas berwarna coklat kehitaman yang menandakan tanah bagian atas tersebut terkontaminasi kotoran ayam. Butiran tanah pada bagian atas sampel lebih gembur dibandingkan pada bagian bawah sampel tanah

Gambar 5 memperlihatkan bahwa arus berbanding lurus dengan beda potensial antar ujung medium (kotoran ayam). Jika nilai gradien grafik merupakan nilai hambatan maka diperoleh nilai hambatan kotoran ayam sebesar $8063 \Omega$. Setelah diperoleh nilai hambatan kotoran ayam, selanjutnya dicari nilai resistivitasnya berdasarkan informasi dari geometri (luas dan panjang) medium uji (kotoran ayam) dan nilai hambatannya berdasarkan persamaan 2. Nilai resistivitas yang diperoleh sebesar $83,184 \Omega \mathrm{m}$, sehingga dari informasi nilai resistivitas akan diperoleh nilai konduktivitas kotoran ayam sebesar $12,02 \mathrm{mS} / \mathrm{m}$.

Nilai konduktivitas pada lahan peternakan juga mendapat perlakuan yang sama dengan medium kotoran ayam, untuk sampel tanah pada kedalaman 0-15 cm maupun 15-30 cm. Nilai konduktivitas masing-masing kedalaman kemudian disatukan dan dibuat peta distribusi konduktivitas lahan peternakan. Distribusi nilai konduktivitas lahan peternakan dapat menjelaskan daerah mana yang tercemar limbah kotoran ayam 


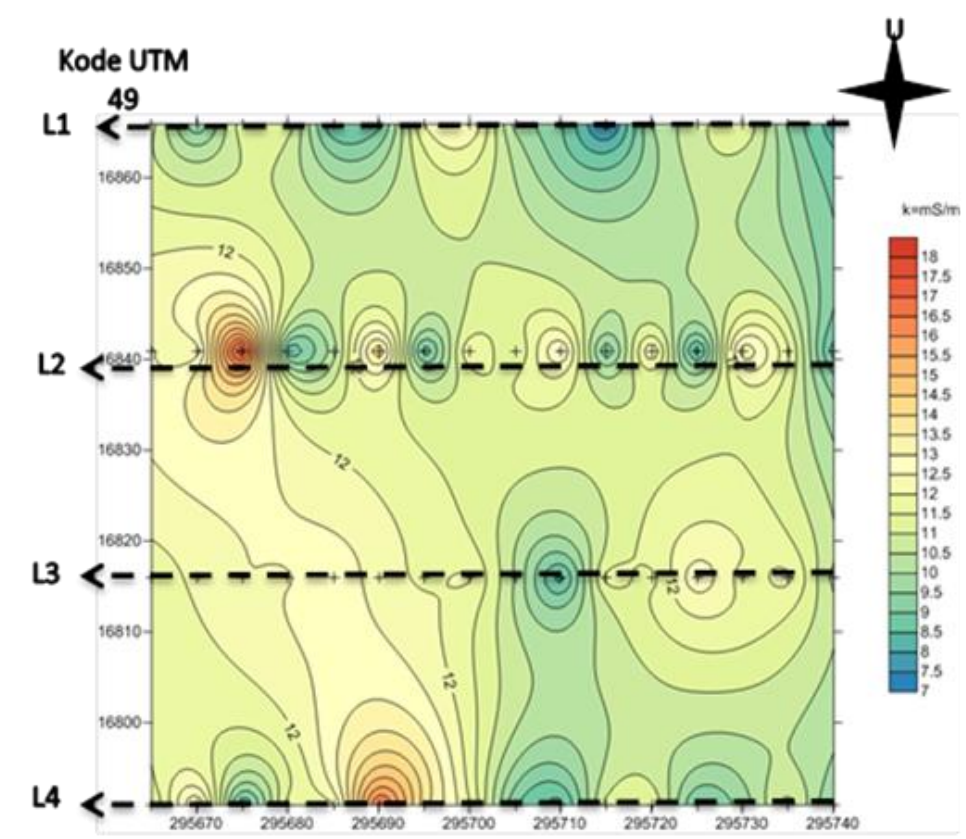

Gambar 6 Pola distribusi konduktivitas pada kedalaman 0-15 cm

Gambar 6 menggambarkan tentang distribusi konduktivitas tanah pada kedalaman 0-15 cm. Lintasan satu (L1) secara garis besar nilai konduktivitasnya cenderung rendah yang berkisar antara $7 \mathrm{mS} / \mathrm{m}$ sampai $10,5 \mathrm{mS} / \mathrm{m}$. Hal ini disebabkan oleh keadaan di sekitar kandang terasa kering dan lebih tinggi. Lintasan kedua (L2) dan lintasan ketiga (L3) nilai konduktivitasnya berkisar antara $9 \mathrm{mS} / \mathrm{m}$ sampai $17 \mathrm{mS} / \mathrm{m}$. Pada lintasan kedua terdapat satu titik yang memiliki nilai konduktivitas lebih tinggi dibandingkan dengan yang lain. Hal ini disebabkan oleh kondisi bidang tanah sedikit menurun dan tanah lebih lembab diantara yang lain. Lintasan keempat (L4) mempunyai nilai konduktivitas berkisar antara 8,5 mS/m sampai $15 \mathrm{mS} / \mathrm{m}$. Pada lintasan keempat (L4) ini terdapat juga satu titik yang cenderung lebih tinggi nilai konduktivitasnya. Penyebab utamanya adalah pada tanah tersebut terdapat tumpukkan kotoran ayam lebih banyak dari yang lain. Keadaan ini bisa saja terjadi jika ayam yang berada pada kandang tersebut berkumpul pada satu titik dan dapat menyebabkan kotoran ayam terkumpul pada satu titik lebih banyak dibandingkan dengan yang lainnya.

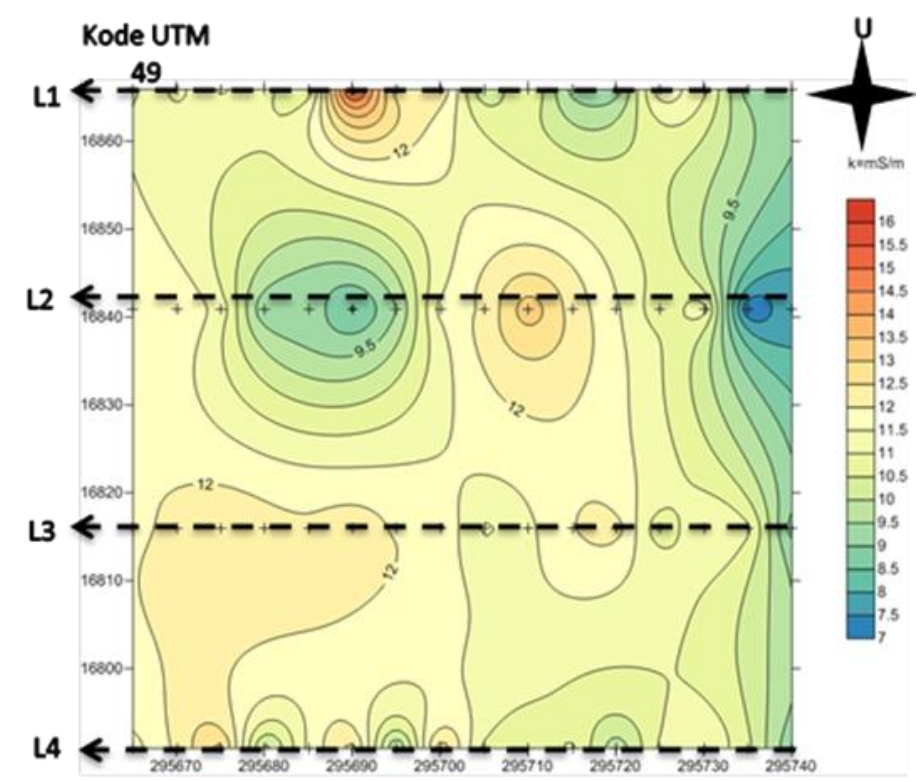

Gambar 7 pola distribusi konduktivitas pada kedalaman $15-30 \mathrm{~cm}$ 
Gambar 7 menunjukkan nilai konduktivitas pada kedalaman 15 hingga $30 \mathrm{~cm}$. Pada Lintasan satu (L1) nilai koduktivitasnya berkisar antara $8,5 \mathrm{mS} / \mathrm{m}$ sampai $14,5 \mathrm{mS} / \mathrm{m}$. Pada lintasan itu juga terdapat titik dengan nilai konduktivitas lebih tinggi. Berbeda dengan lintasan satu, lintasan kedua (L2) memiliki nilai konduktivitas berkisar antara $7 \mathrm{mS} / \mathrm{m}$ sampai $13 \mathrm{mS} / \mathrm{m}$ dan terdapat tiga titik yang mempunyai nilai berbeda, dua titik mempunyai nilai konduktivitas rendah dan satu titik mempunyai nilai konduktivitas yang tinggi. Titik yang mempunyai konduktivitas rendah diduga karena kandungan kotoran ayam tidak sampai pada kedalaman ini sehingga nilainya sedikit lebih rendah. Kemudian Pada lintasan ketiga (L3) dan lintasan keempat (L4) nilai konduktivitasnya tidak terlalu jauh berbeda yang berkisar antara $9 \mathrm{mS} / \mathrm{m}$ sampai $12 \mathrm{mS} / \mathrm{m}$. pada lintasan tersebut nilainya cenderung sama dan dapat diduga bahwa kandungan kotoran ayam tercampur merata meskipun tidak meliputi seluruh area pada lintasan tiga (L3) dan lintasan empat (L4).

Berdasarkan Gambar 6 dan 7 dapat dilihat bahwa sebaran dengan nilai konduktivitas tinggi terletak pada sisi Barat lahan peternakan. Hal ini disebabkan daerah tersebut merupakan daerah yang lebih rendah dibandingkan sebelah sisi Timur pada lahan peternakan, sehingga limbah kotoran ayam akan terakumulasi ke sisi Barat.

\section{Kesimpulan}

Berdasarkan hasil penelitian dapat disimpulkan bahwa nilai konduktivitas kotoran ayam adalah 12,02 mS/m. Daerah kedalaman 0$15 \mathrm{~cm}$ memiliki nilai distribusi konduktivitas sebesar 7-18 $\mathrm{mS} / \mathrm{m}$ dan kedalaman $15-30 \mathrm{~cm}$ sebesar 7-16 $\mathrm{mS} / \mathrm{m}$ dengan nilai konduktivias limbah kotoran ayam terdistribusi ke arah barat lahan peternakan ayam.

\section{Daftar Pustaka}

[1] Souisa, M. dan Sapulete, S.M, Kajian Sebaran Limbah Cair Menggunakan Metode Resistivitas, Seminar Nasional, Lontar Physics Forum, Hal. 3-4, 2013.

[2] Prasetyanto Nova, Kadar H2S, NO2, dan Debu Pada Peternakan Ayam Broiler Dengan Kondisi Lingkungan Yang Berbeda di Kabupaten Bogor Jawa Barat, Jurusan Ilmu Produksi dan Teknologi Peternakan,Institut Pertanian Bogor, 2011.

[3] Juandi, Analisis Air Bawah Tanah dengan Metode Geolistrik. Jurnal Ilmu Lingkungan, Vol I, No. 2, Hal. 2-6, 2008.

[4] Arman Yudha, Identifikasi Struktur Bawah Tanah di Kelurahan Pangmilang kecamatan Singkawang Selatan Menggunakan Metode Geolistrik resistivitas Dan Inversi Lavenberg-
Marquardt, Jurnal Positron, Vol. II, No. 1, Hal. 0611, 2012.

[5] Google Earth. Diambil kembali dari http://www.earthgoogle.com (21 Maret 2019). 